\title{
SUPPLY CHAIN OPERATION REFERENCE ANALYSIS OF LOCAL VEGETABLE E-COMMERCE
}

\author{
Hamdani Hamdani")1, Wahyudin Wahyudin*), and Billy Nugraha*) \\ ${ }^{*}$ Industrial Engineering Departement, Universitas of Singaperbangsa Karawang \\ Jl. H.S. Ronggowaluyo, Telukjambe Timur, Kabupaten Karawang 41361, Indonesia
}

\begin{abstract}
This study aims to determine the chain of sales of vegetables in Teluk Jambe, Karawang Regency. In addition, it can cut off the chain of sales from farmers to consumers. While the scope of this study only discusses the vegetables only. This research type is descriptive qualitative and done with the concept of qualitative descriptive. Descriptive qualitative is the concept of research with the process of obtaining data that is potluck. Analyze the supply chain of vegetables commercial with the methods of Supply Chain Operation Reference (SCOR). The results of the study showed the presence of Sis-Log In Apps could be cut chain sales. So from the results of this study provide a positive impact for farmers. In conclusion, Sis-Log In Apps is designed to cut the chain of sale of commodity vegetables only. With the results as a liaison and direct intermediaries between farmers and consumers.
\end{abstract}

Keywords: Agriculture, e-commerce, SCM, SCOR, Sis-Log In Apps

Abstrak: Penelitian ini bertujuan untuk mengetahui mata rantai penjualan komoditas sayuran di Teluk Jambe, Kabupaten Karawang. Selain itu, dapat memotong mata rantai penjualan dari petani sampai konsumen. Sementara ruang lingkup penelitian ini hanya membahas komoditas sayuran saja. Penelitian ini berjenis deskriptif kualitatif dan dilakukan dengan konsep kualitatif deskriptif. Kualitatif deskriptif adalah konsep penelitian dengan proses memperoleh data yang bersifat seadanya. Maka untuk menganalisis rantai pasok sayuran komersil dengan metode Supply Chain Operation Reference (SCOR). Hasil dari penelitian menunjukkan dengan adanya Sis-Log In Apps dapat memotong mata rantai penjualan. Sehingga dari hasil penelitian ini memberikan dampak positif bagi petani. Kesimpulannya Sis-Log In Apps dirancang sebagai pemutus mata rantai penjualan komoditas sayuran saja. Dengan hasil sebagai penghubung dan perantara langsung antara petani dengan konsumen.

Kata kunci: Pertanian, e-commerce, SCM, SCOR, Sis-Log In Apps

${ }^{1}$ Corresponding author:

Email: hamdanixitsmb@gmail.com 


\section{INTRODUCTION}

Healthy eating behavior is a variation of the recommended food groups, namely: carbohydrates, fruits, vegetables, proteins, and fats that are generally applicable (Fatimah \& Siregar, 2020). Vegetables and fruit are a source of micronutrients that are beneficial to the body. This is because both component's nutrition is very important in the body's metabolic processes as a regulator of substances and antibodies. In addition, it would be useful to prevent chronic diseases (Putra, 2016). According to the World Health Organization (WHO), recommendations comparison between fruits and vegetables, as many as 400 grams/day or as much as 3-5 serving/day.

Meanwhile, the Food Pyramid recommends presenting the fruit as much as 2-4 serving and vegetables as much as 3-5 serving in a day (Suyatno et al. 2015). Consumption of fruits and vegetables in Indonesia can still be said to below. It looks at the average consumption of vegetables, 57.1 grams/person/day. While the average consumption of the fruit the 33.5 grams/person/day (Dhaneswara, 2016).

The proportion of the highest population who consume vegetables and milk in a leaf vegetable, namely 56,8 grams/person/day. While the types of other vegetables only consumed less than 10 grams/person/day. The proportion of the population who consume the vegetables looks high in Group 19-55 years. In the year 2016 , with the consumption of fruit and vegetables, Indonesian citizens decreased. Only $43 \%$ of the amount recommended by Recommended Dietary Allowances (RDA)(Rahmatunisa et al. 2019). While seen from the business factors, the agricultural sector has a strategic role in the structure of national economic development one part of the industry's horticulture subsector that increases the contribution. Can be aware of the Gross Domestic Product (GDP) value of the national with the current price of $1.45 \%$ in 2012 to $1.52 \%$ in 2015 (Paramita et al. 2019; Apriyani et al. 2018).

But on the other hand, there are problems in the marketing of vegetables commercial. Some of the problems in the form of high prices enjoyed by farmers, the price of vegetables fluctuates, and consumers still meet their needs (Soka et al. 2017). This study aims to determine the chain of sale of vegetables in Teluk Jambe, Karawang Regency. In addition, it may cut chain sales from farmers to consumers. While for this research's status is the result of the development of the research done before, namely the design of the application named Sis-Log In Apps. To prove whether the application conforms with the concept. Then carried out this study by using the method of Supply Chain Operation Reference (SCOR). SCOR is the reference model of the process that combines various concepts in engineering. In addition, the prepared based on the five processes: plan, source, make, deliver and return. So, SCOR can prove the results of the analysis of this study.

Supply chain management is the integration of the various materials and services procurement activities. In addition, the conversion into semi-finished goods and final products and delivery to customers (Kasengkang et al. 2016; Sari et al. 2017). Logistics is the process of planning, implementing, and controlling the efficient flow and effectiveness of goods or services and information. Then the logistics objective is to get the right goods at the right time and with the right amount. In addition, the right conditions, at an affordable cost and with a fixed contribution profit for logistics service providers (Kasengkang et al. 2016; Maulidah \& Megayanti, 2016). Schroeder (2007) found that measuring the supply chain's performance is the first step towards repair. The early stages need to be set and determined to be able to achieve the purpose of improvement. Schroeder suggests that, in general, five important points can be measured in the performance of the supply chain (Rantung et al. 2016; Saputro, 2019; Schroeder, 2007), as follows:

1. Shipping, which refers to punctuality. The percentage of orders delivered in full and not pass on the date requested by the customer. The quality of the direct Measure is customer satisfaction and can be measured in several ways. One of them can be measured against what customers expect. This measurement is closely related to customer loyalty.

2. Time, i.e., the charging amount, can be calculated directly from the inventory level. If it is assumed, there is a level of constant use from the inventory. Then the time in the inventory only inventory levels divided by the level of use.

3. Flexibility, i.e., the time it takes to change the volume or product mix by a certain percentage.

4. Cost that can measure the shipping costs, such as manufacturing, distribution, the cost of the inventory recorded, and the cost of accounts receivable. 
Here are some of the previous studies are used as parameters in this study. Research conducted by Akbar Abbaspour: This standard framework of criteria and processes improves supply chain capabilities (Abbaspour, 2019). Research conducted by William Y. C. Wang, Hing Kai Chan, and David J. Pauleen: Causes/Effects, the SCOR Standard, and Mutual Solution (CESM) (Wang et al. 2009). Research conducted by Lamia Hammadi, Eduardo Souza de Cursi, Vlad Stefan Barbu, Abdellah Ait Ouahman, and Aomar Ibourk: Moreover, this model provides a general framework to promote a better understanding of a particular customs supply chain using mapping (Hammadi et al. 2012). Research conducted by Taufik Djatna, Marimin, Muhammad Asrol, Taufik Baidawi, Harison, Safriyana and Sri Martini: The integration of JavaScript-based front-end with the SCOR-based database operation is ready for mobile and desktop usage (Djatna et al. 2020). Research conducted by Piyanee Akkawuttiwanich and Pisal Yendradee: This method is new in the performance evaluation framework using a SCOR model (Akkawuttiwanich \& Yenradee, 2017). Research conducted by Houshang Taghizadeh and Ehsan Hafezi: Finally, using the formulas of calculating the reliability in combined systems, the reliability of each system and ultimately the whole system is investigated (Taghizadeh \& Hafezi, 2012). Research conducted by Yamuna Rani Palanimally: Still sustain a decrease in sales, decrease in number employees, decrease in total assets and decrease in profit after the global recession (Palanimally, 2016). Research conducted by Sachin S. Kamble, Angappa Gunasekara, and Shradha A. Gawankar: The framework will guide the practitioner to plan their investments to build a robust data-driven agri-food supply chain (Kamble et al. 2020). Research conducted by Lee Khai Loon, Gusman Nawanir, Zahari Abu Bakar and Jalal Hanaysha: The discussion of this study is followed by presenting the results of the survey on the relationship of relational capability and organizational culture capability on supply chain operational performance (Loon et al. 2019). Research conducted by Archie Lockamy III and Kevin McCormack: Based on the four decision areas provided in SCOR model version 4.0 (Plan, Source, Make, Deliver) (III \& McCormack, 2004).

While following some of the previous research that used the alternatives' parameters in this study: Abla Chaouni Benabdellah, Asma Benghabrit, Imane Bouhaddou and El Moukhtar Zemmouri: Big data have the potential to revolutionize supply chain dynamics
(Benabdellah et al. 2016). Research conducted by Seyed Mahdi Hosseini Nasab, Sayyed Mahdi Ziaei and Mohd Norfian Alifiah: So today is the implementation of supply chain management as one of the foundations of e-business infrastructure around the world (Nasab \& Sayyed, 2015). Research conducted by Bijan Ganji Jamehshooran, Awaluddin M Shaharoun and Habibah Norehan Haron: The study combined resource-based theory, in improving supply chain performance (Jamehshooran et al. 2015). Research conducted by Elisa Kusrini, Suci Miranda and Gunawan Muhammad: Based on Version 11.0 of the SCOR-model: plan, source, deliver, return and enable (Kusrini et al. 2019). Research conducted by Maziyar Golparvar and Mehdi Seifbarghy: Supply chain operations reference (SCOR) model is developed and maintained by the supply chain council (SCC) (Golparvar \& Seifbarghy, 2009). Research conducted by Honggeng Zhou, Jr. W. C. Benton, David A. Schilling and Glenn W. Milligan: The supply chain operations reference (SCOR) model has been widely adopted in many companies (Zhou et al. 2011). Research conducted by Sawarni Hasibuan and Nurul Dzikrillah: The recommended improvements are to provide training on-demand analysis (Hasibuan \& Dzikrillah, 2018). Research conducted by Sara Elgazzar, Nicole Tipi, Nick Hubbard and David Leach: Purpose of evaluating and improving supply chain operations'performance(Elgazzar etal.2011). Research conducted by Essajide Lhassan and Rachidi Ali: SCOR model helps map and analyze the entire supply chain (Lhassan \& Ali, 2017). Research conducted by Ike Ehie and Luis Miguel D. F. Ferreira: Based view of the firm to ascertain the transformational effect of supply chain digitalization (Ehie \& Ferreira, 2019).

The connection between previous research with this study on the analysis of the chain of distribution of products from the farmers to the consumers. In addition, the technique of analysis of performance by using Supply Chain Operations Reference (SCOR) (Lubis et al. 2018). This is to determine the performance of the Supply Chain Management. Development is done by creating an application that directly serves as a liaison and intermediary between the farmer and the consumer to optimize the sale price by the farmer.

The renewal of this research is the adjustment in the use of the Supply Chain Operations Reference (SCOR) process. Only using 3 of the process, namely the planning, delivery, and refund of the amount 5, is there. This is because to adjust with the research 
done, only examine the flow of sales without the view from the product's side of procurement. In addition, it examines the flow of the chain of sales of vegetables. Development research is a well-designed application to cut the chain of sales. The app serves as a liaison and intermediary directly between farmers and consumers.

\section{METHODS}

Here below is the flow of research conducted. As in figure 1. Description of the stages of groove research such as in Figure 1. above as follows:

1. Start, namely the marking since the start of this study on September 12, 2020.

2. Preparation of Research, namely the study of literature and field studies with the following explanation: Literature Study is done by studying the references in scientific articles, proceedings, books, and other literature; A field study was conducted to observe the accurate information in the study.

3. Identification of the problem, namely the determination of the foundation for the research. This stage is built based on the formulation of the problem based on the background. The problems found in the form of assessment of the chain of sales of vegetables, from farmers to consumers.

4. Methodology of research carried out by formulating the flow of research. it is at the start of the preparation of the study until data analysis.

5. Data collection, carried out to obtain the information needed. The Data used is primary data. The method of data collection is done by interview and distributing questionnaires.

6. Data analysis, this research type is qualitative descriptive. In addition, analysis was done with methods of descriptive qualitative. Qualitative descriptive analysis analyzes commercial vegetables' supply chain, such as spinach, tomatoes, potatoes, and red onion.

This is done with the methods of Supply Chain Operation Reference (SCOR). SCOR is the reference model of the process that combines various concepts in engineering. In addition, the prepared based on the five processes: plan, source, make, deliver and return.
The hypothesis of this study is obtained from the method of SCOR. So, that is specified for the attribute labor as follows: Reliability, Responsiveness, and Cost. While the results of the matrix for each attribute labor above as follows: Order Sent in Full, Delivery performance, The Accuracy of the Documentation, The Condition of the Goods, The Cycle Time of Delivery, and Delivery.

\section{RESULTS}

Previous research was conducted in the Village Linggarsari, District Telagasari, Karawang Regency. In addition, the participants in the study involved a group effort of farmers, agricultural extension workers, students, faculty, and the surrounding community. Then to continue the results of previous studies, conducted this study by using the method of SCOR. It aims to analyze the results of the design of the application that has been made. Sis-Log is an app purchasing which is explicitly designed for vegetables in Karawang Regency. In this app, farmers can sell the direct result of the vegetables ready to harvest to consumers without going through an intermediary. It aims to cut the chain of the sale of vegetables. So that farmers can enjoy the same price in the market. In addition, this app can make it easier for consumers to search for and meet the needs of vegetables day-to-day. As for the content of the appearance of the application as in Figure 2. The initial conditions describe the sales process before using the application Sis-Log In. As in Figure 3.

Based on Figure 3 illustrates the flow distribution of vegetables from farmers to consumers, precisely at Teluk Jambe - Karawang. Look vegetables experience some time sojourn, i.e., in the collectors and traders. This resulted in prices that are in sell on the consumer tend to be high and inversely proportional to the farmers. In addition, there is a discrepancy in the acquisition of the profit margins obtained by farmers compared with the collectors and traders. Meanwhile, the impact of flow distribution length will decrease the quality and freshness of the vegetables sold. Clearly, from the plot, namely, the results of the harvest are collected by the farmers. Then take it to market to sell to retailers or wholesalers. 


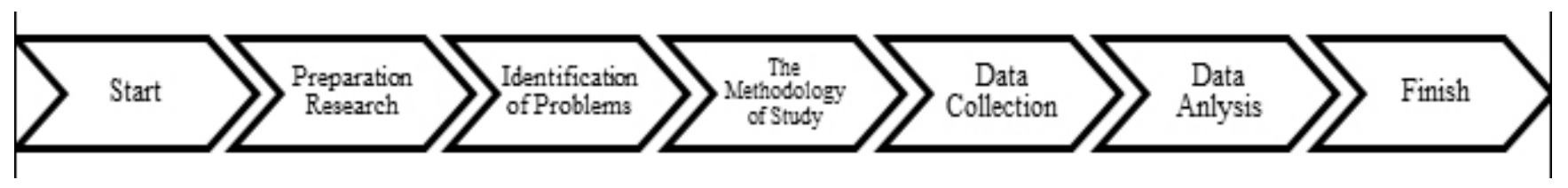

Figure 1. The stages of flow research application of e-commerce

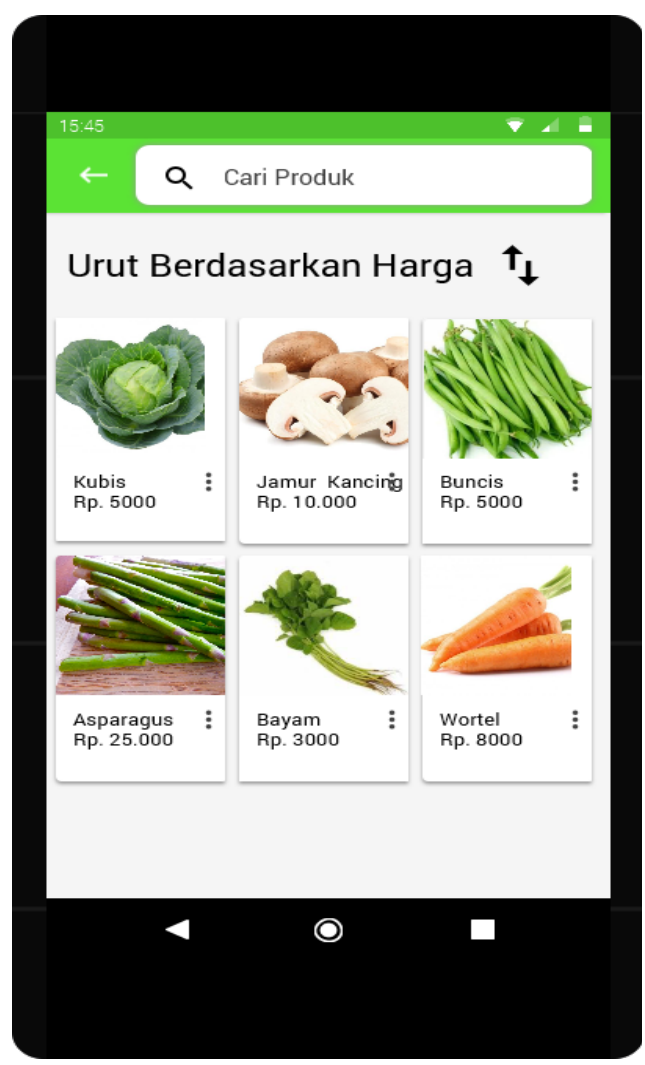

Figure 2. Sis-Log In Apps
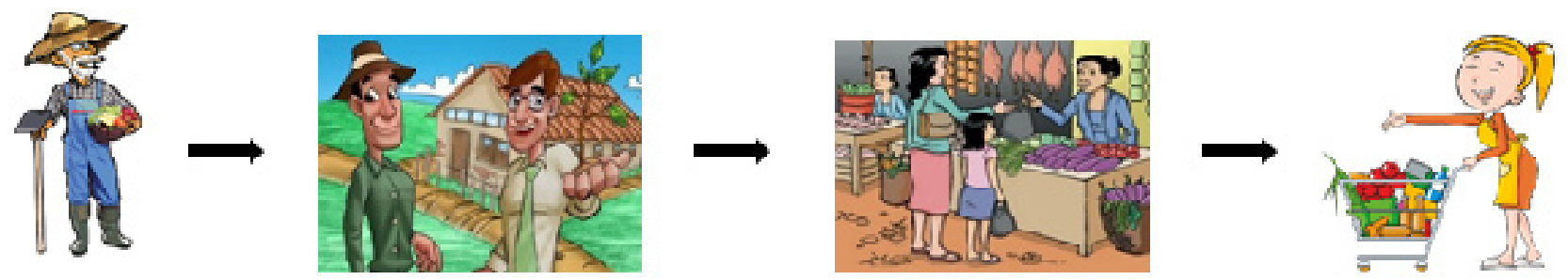

Figure 3. Illustration of the chain of distribution the sale of vegetables before the application of e-commerce

Furthermore, from the wholesalers sell to the retailers in the market, retailers can be sold to the consumer. However, the harvest purchased directly by the consumer to the farmer is also the result of the freshness of the vegetables in the buy. The case with that in the buy from a retailer as an example of the process of cabbage up into the hands of retailers must be through the farmers themselves or collectors. This will take a long time. Then what happens on the quality of the leaves or petals of the cabbage is already visible black splotches. In terms of making the process of the supply chain and the transaction is simple. Then the role of wholesalers and retailers or traders is replaced by the application. As in Figure 4. 

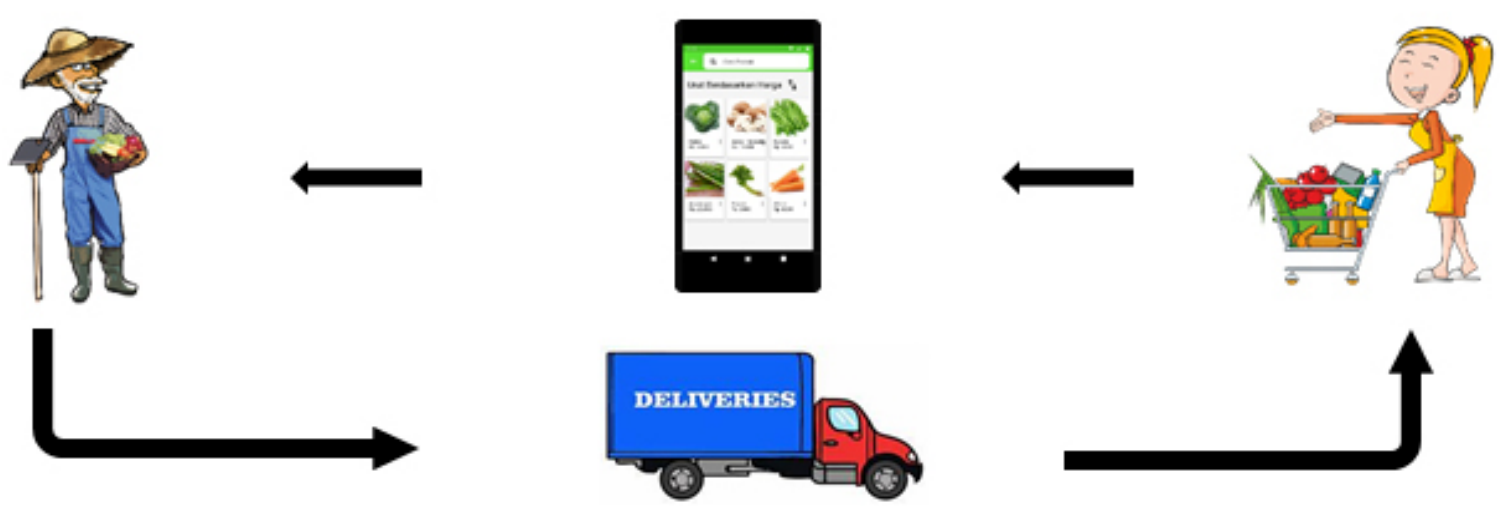

Figure 4. Illustration of the chain of distribution the sale of vegetables after the application of e-commerce

Based on Figure 4 the Sis-Log In Apps acts as a liaison between consumers and farmers directly. Consumers can search for the required vegetables, then connected with the farmers who provide them. Furthermore, the farmers will send the vegetables to consumers directly so that the consumer's vegetables will be of high quality. This is because it comes directly from farmers without any other intermediaries. In addition, farmers can enjoy a higher selling price than the previous process. As shown in Figure 2, above can be measured to determine the supply chain's performance, among others, in terms of effectiveness and efficiency. The effectiveness of using the methods of Supply Chain Operations References (SCOR). While measuring the efficiency of using marketing margin and farmer's share.

The process of supply chain method Supply Chain Operations Reference (SCOR) consisting of five processes. In between planning, procurement, production, delivery, and refunds, this study only uses planning, shipping, and returns. Explanations about the components of the SCOR in the supply chain of vegetables as follows:

1. Process Planning is an activity of the supply chain as a whole. Starting from production planning, delivery planning vegetable commercial (such as spinach, tomatoes, potatoes, and red onion), and the planning of return. At the time of the research, the vegetable business planning has been accomplished quite well at the start of the planning and design of a Sis-Log In Apps in as media new marketing.

2. The Process of Sending vegetable commercials done by the farmers directly. Before delivery, there is a process of transactions and agreements made on the application. Buyers are looking for and choose vegetables that are needed through the app. Then the consumer performs a contact communication with farmers regarding the details of the shopping will be done. After the done deal, then farmers send vegetables directly booked. Delivery requires transportation costs. It was agreed when the contact process communication.

3. The Process of Return, i.e., transaction of vegetables, is not much done. When damage occurs to the goods during the delivery of the goods, it is not returned. But the reduced volume of a kilogram or the price.

As for the attributes of supply chain performance in this study. As in Table 2. Since this research type is descriptive qualitative and done with the concept of qualitative descriptive, then the process of obtaining data is a potluck. So the research results in the form of a hypothesis that is based on the method of SCOR. As in Table 2.

Then to analyze the supply chain of vegetables commercial with the Supply Chain Operation Reference (SCOR). To attribute labor consists of Reliability, Responsiveness, and Cost. The matrix consists of: Order is Sent in Full, Delivery performance, The Accuracy of The Documentation, The Condition of the Goods, The Cycle Time of the Delivery, and Delivery. While the research results are easy to understand, the rich picture diagram explains the concept of research. As in Figures 2 and 3. The visualization of the image gives an illustration of the concept of the research being conducted. 
Table 2. Attributes work the supply chain

\begin{tabular}{|c|c|c|}
\hline Attribute Labor & Matrix & Buyer \\
\hline \multirow[t]{4}{*}{ Reliability } & Order Sent In Full & $\begin{array}{l}\text { Orders are shipped } 100 \% \text { can be met by the farmers which are listed on } \\
\text { the application. }\end{array}$ \\
\hline & Delivery Performance & $\begin{array}{l}\text { The shipping done by the farmers in accordance with the agreement } \\
\text { agreed on the application. So the delivery is already scheduled and } \\
\text { estimated departure and arrival times. }\end{array}$ \\
\hline & $\begin{array}{l}\text { The Accuracy of the } \\
\text { Documentation }\end{array}$ & $\begin{array}{l}\text { At the time of receiving the order, the buyer receives a receipt which is } \\
\text { brought by farmers to give details of the purchase and as proof of the } \\
\text { transaction. }\end{array}$ \\
\hline & $\begin{array}{l}\text { The Condition of the } \\
\text { Goods }\end{array}$ & $\begin{array}{l}\text { Damage to the goods accepted at the time of travel, the farmers simply } \\
\text { cut the amount of the scales or reduce the price. }\end{array}$ \\
\hline Responsiveness & $\begin{array}{l}\text { The Cycle Time of } \\
\text { Delivery }\end{array}$ & $\begin{array}{l}\text { Vegetables are delivered by farmers in accordance with the agreed time } \\
\text { on the application. }\end{array}$ \\
\hline Cost & Delivery & $\begin{array}{l}\text { The cost of delivery is borne by the buyer based on the distance traveled } \\
\text { by farmers. }\end{array}$ \\
\hline
\end{tabular}

\section{Managerial Implication}

The agricultural sector has an important role in the structure of Indonesian economy development. Therefore it is necessary to handle good in maximizing the sector. SIS-Log in Apps can cut the chain of vegetable commodity sales in Karawang. So farmers can maximize the benefits of sales of vegetables. This is because the transaction process no longer involves collectors. Thus it is expected that the agricultural sector can be welfare of farmers.

\section{CONCLUSIONS AND RECOMMENDATIONS}

\section{Conclusions}

Based on research results, the grooves of the chain of sales of vegetables in Telukjambe - Karawang are profitable for farmers. This is due to the sale of vegetables involves the middlemen and traders before to the consumer. So a higher selling price is not enjoyed by farmers but rather by collectors and traders.

Application Sis-Log In was designed as a breaker of the chain of sales of vegetables. In addition, it acts as a liaison and direct intermediaries between farmers and consumers. So that farmers can enjoy the same price in the market. Then the consumer can enjoy quality fresh vegetables because the vegetables come directly from the farmers.

\section{Recommendations}

Based on the study conducted, the development of marketing applications needs to consider shipping costs. Because the transaction process does not stop after the payment process, but it is necessary to delivery the goods. Recommendations for further research are taking into account the range of consumers and farmers. This range affects when consumers make a transaction then the order is handled by the nearest farmer. This aims to minimize shipping costs. Besides that Tempilan on the application that is still simple and needs to add back features.

\section{REFERENCES}

Abbaspour A. 2019. Supply chain analysis and improvement by using the SCOR model and fuzzy ahp: a case study. International Journal of Industrial Engineering \& Management Science, 5(2):51-73.

Akkawuttiwanich P, Yenradee P. 2017. Evaluation of SCOR KPIs using a predictive MILP model under fuzzy parameter. International Journal of Supply Chain Management 6(1):172-185.

Apriyani D, Nurmalina R, Burhanuddin. 2018. Evaluasi kinerja rantai pasok sayuran organik dengan pendekatan supply chain operation reference. Jurnal Ilmiah Manajemen 8(2):312-335. https:// doi.org/10.22441/mix.2018.v8i2.008.

Benabdellah AC, Benghabrit A, Bouhaddou I, Zemmouri EM. 2016. Big data for supply chain management: opportunities and challenges. International Journal of Scientific \& Engineering 
Research 7(11): 20-26. https://doi.org/10.1109/ AICCSA.2016.7945828.

Dhaneswara DP. 2016. Faktor yang mempengaruhi niat makan sayur dan buah pada mahasiswa asrama Universitas Airlangga. Jurnal Promkes 4(1):3447. https://doi.org/10.20473/jpk.V4.I1.2016.3447.

Djatna T. et al. 2020. SCOR-based information modeling for managing supply chain performance of palm oil industry at Riau and Jambi Provinces, Indonesia. International Journal of Supply Chain Management 9(5):75-89.

Ehie I, Ferreira LMDF. 2019. Conceptualdevelopment of supply chain digitalization framework. International Federation of Automatic Control (IFAC), LII(13):2338-2342. https://doi. org/10.1016/j.ifacol.2019.11.555.

Elgazzar, S., Tipi, N., Hubbard, N. \& Leach, D., 2011. A SW Application System for Measuring Supply Chain Operations' Performance Using SCOR FAHP Technique. Singapore, 2011 International Conference on Business and Economics Research (IPEDR).

Fatimah PS, Siregar PA. 2020. Konsumsi buah, sayur dan ikan berdasarkan sosio demografi masyarakat pesisir Provinsi Sumatera Utara. Contagion: Scientific Periodical of Public Health and Coastal 2(1):51-63. https://doi.org/10.30829/ contagion.v2i1.7630.

Golparvar M, Seifbarghy M. 2009. Application of SCOR model in an oil-producing company. Journal of Industrial Engineering 4(4):59-69.

Hammadi L et al. 2012. A SCOR Model for customs supply chain process design. International Network of Customs Universities 12(2): 95-106.

Hasibuan S, Dzikrillah N. 2018. Supply chain performance measurement and improment for indonesia chemical industry using SCOR and DMAIC Method. Saudi Journal of Engineering and Technology (SJEAT) 3(3):146-155.

III AL, McCormack K. 2004. Linking SCOR planning pracices to supply chain performance an exploratory study. International Journal of Operations \& Production Management, 24(12):1192-1218. https://doi. org/10.1108/01443570410569010.

Jamehshooran BG, Shaharoun AM, Haron HN. 2015. assessing supply chain performance through applying the SCOR Model. International Journal of Supply Chain Management 4(1):1-11.

Kamble SS, Gunasekaran A, Gawankar SA. 2020.
Achieving sustainable performance in a datadriven agriculture supply chain: a review for research and applications. International Journal of Production Economics 2(19):179-194. https:// doi.org/10.1016/j.ijpe.2019.05.022.

Kasengkang RA, Nangoy S, Sumarauw J. 2016. Analisis logistik (studi kasus pada PT. Remenia Satori Tepas-Kota Manado). Jurnal Berkala Ilmiah Efisiensi 14(1):750-759.

Kementrian Kesehatan Republik Indonesia - Kemenkes RI, 2014. Studi Diet Total: Survei Konsumsi Makan Individu Indonesia 2014. 1st ed. Jakarta: Badan Penelitian Pengembangan Kesehatan.

Kusrini E, Miranda S, Muhammad G. 2019. Design for supply chain performance assessment in supermarket. International Journal ofInnovation, Management and Technology 10(1):66-71. https://doi.org/10.18178/ijimt.2019.10.1.838.

Lhassan E, Ali R. 2017. Planning and modelling of pharmaceuticals wholesale-distributors supply chain using SCOR Model: A Morrocan Case Study. International Journal of Management Sciences and Business Research 4(3): 35-51.

Loon LK, Nawanir G, Bakar ZA, Hanasysha J. 2019. Strengthening supply chain operational performance through relational and organizational culture capabilities. International Journal of Supply Chain Management 8(4): 9098.

Lubis IH, Djatna T, Novianti T. 2018. Performance improvement strategy of supply chain management in Sei Galuh Palm Oil Mill, PT Perkebunan Nusantara V. Jurnal Manajemen \& Agribisnis 15(3):280-288. https://doi. org/10.17358/jma.15.3.280.

Maulidah S, Megayanti F. 2016. Analisisefisiensi distribusi pada penjualan produk olahan buah dan sayuran dengan metode Data Envelopment Analysis (DEA). Jurnal Sosial Ekonomi dan Kebijakan Pertanian 5(2):188-197. https://doi. org/10.21107/agriekonomika.v5i2.1594.

Nasab SMH, Sayyed Mahdi Ziaei MNA. 2015. The mediating effect of supply chain agility on the relationship between SCOR business analytic solution and supply chain performance. American Journal of Business, Economics and Management 3(4):171-176.

Palanimally YR. 2016. The Growth of small and medium entreprises in malaysia: a study on private limited companies in Perak Malaysia. IOSR Journal of Economics and Future (IOSR- 
JEF) 7(3):55-60.

Paramita YS, Hasyim AI, Affandi MI. 2019. Analisis rantai pasok tomat di Kecamatan Sukau Kabupaten Lampung Barat. Jurnal Ilmu Ilmu Agribisnis 7(4):499-506.

Putra WK. 2016. Faktor-faktor yang Berhubungan dengan Konsumsi Buah dan Sayur pada Anak Sekolah Dasar (Studi Kasus pada SDN 1 dan SDN Pekunden Semarang), Semarang: Jurusan Ilmu Kesehatan Fakultas Ilmu Kedok di Lampiran.

Rahmatunisa R, Kurniasari R, Andriani E. 2019. Gerakan Masyarakat Hidup Sehat (GERMAS) "ayo makan buah dan sayur pada siswa SMAN 1 Teluk Jambe Timur Karawang". Jurnal Cemerlang: Pengabdian Kepada Masyarakat 4(2):13-23. https://doi.org/10.31540/jpm. v2i1.597.

Rantung ML, Adolfina P, Wenas RS. 2016. Analisis kinerja rantai pasok komoditas kacang tanah di pasar tradisional beriman Kota Tomohon. Jurnal EMBA 2(4):849-858.

Saputro N Y. 2019. Analisis Supply Chain Management (SCM) Komodias Cabai Rawit Merah di Kecamatan Getasan, Kabupaten Semarang. Madiun, Seminar Nasional Teknologi Informasi dan Komunikasi 2019:267-271.

Sari IRM, Winandi R, Tinaprilla N. 2017. Kinerja rantai pasok sayuran dan penerapan contract farming models. Jurnal Ilmiah Manajemen, 7(3):498-
517.

Schroeder RR. 2007. Operations Management Contemporary Concepts and Cases. 3rd ed. Singapore: McGraw Hill International Edition.

Soka TD, Miftah H, Yoesdiarti A. 2017. Kinerjarantai pasok sayuran komersial di pasar tradisional Kota Bogor. Jurnal AgribiSains 3(2):23-31. https://doi.org/10.30997/jagi.v3i2.1047.

Suyatno S, Aruben R, Kartika D. 2015. Faktor-faktor yang mempengaruhi konsumsi makan buah dan sayur pada anak pra sekolah Paud TK Sapta Prasetya Kota Semarang. Jurnal Kesehatan Masyarakat 3(1):244-255.

Taghizadeh H, Hafezi E. 2012. Theinvestigation of supply chain's reliability measure: a case study. Journal of Industrial Engineering International 8(22):1-10. https://doi.org/10.1186/2251-712X$8-22$.

Wang WYC, Chan HK, Pauleen DJ. 2009. Aligning business process reengineering in implemeting global supply chain systems by the scor model. International Journal of Production Research XLVIII(19):1-27. https://doi. org/10.1080/00207540903168090.

Zhou H, Benton JWC, Schilling DA, Milligan GW. 2011. Supply chain integration and the scor model. Journal of Business Logistics 32(4): 332-344.https://doi.org/10.1111/j.00000000.2011.01029.x. 